\title{
Linguistic Features and Local Wisdom Content in EFL Student's Narrative Texts
}

\author{
T. Thyrhaya Zein, T. Silvana $\operatorname{Sinar}^{1}$, Nurlela $^{1}$ \\ ${ }^{1}$ Faculty of Cultural Sciences, Universitas Sumatera Utara, Medan, Indonesia \\ Email: tirasinar@gmail.com
}

\begin{abstract}
This study is aimed to investigate linguistic features and local wisdom content in EFL students' narrative texts and its pedagogical implementation. This study employed qualitative content analysis method as the research design. Writing sheet was used as the instrument of the research. The data were taken from narrative text written by 25 EFL students of STKIP Tapanuli Selatan under the theme of folktales from North Sumatera. The data were analyzed by using experiential function in systemic functional grammar theory to identify linguistic features of the text and Sibarani's concept to discover kinds of local wisdom content in the text. The findings present that there are 12 different titles of folktales found in the data. In term of linguistic features of the text, it is commonly found that most of the students have difficulties in distinguishing the use of past tense or present tense which includes regular and irregular verbs, and the missing of dialogue existence. From local wisdom content, the characteristics illustrated from the texts are keeping promise, obedience to parents, honesty, being not arrogant, and patience. The implication is the students' are not able to write narrative texts properly due to some missing linguistic features and they could not identify local wisdom contents in it. Then, it is also suggested that students do more practices in writing this text and lecturers should take a deep attention in teaching this text so that students can understand and use linguistic features, and insert local wisdom content in narrative text.
\end{abstract}

\section{Keywords: linguistic features; local wisdom; narrative text; systemic functional grammar}

\section{INTRODUCTION}

Writing should be acquired by students and has always formed part of the syllabus in the teaching of English. The ability to produce narrative text is a compulsory for English and literature department student since this text is formed part in the syllabus. When students can't write a good narrative text, they are unable to pass the course. A good narrative text is a text which fulfills lexico grammatical features, schematic or generic structure and social function of narrative text. Every single text is unique. There are some specific linguistic features (lexico-grammar) of every genre that makes them different each other. Halliday [2] suggests that an investigation of the lexicogrammatical stratum of language reveals the kinds of internal patterns of clause structures which are highly favored for interpreting experience. 
Gerot and Wignell [8] assert that narrative text has communicative purpose namely in order to entertain the readers. Anderson and Anderson [1] and Joyce and Feez [8] propose that the structures of narrative include orientation, complication, evaluation, resolution, and coda. Then, Joyce \& Feez [8]) also suggest that narratives have some linguistic features such as specific often individual participants with defined identities, mainly use action verb (material processes), normally use past tense, the use of dialogue, descriptive language, and can be written in the first person (I, we) or third person (he, she, they). Transitivity is a general way how phenomena of the real world are represented as linguistic structures [8]. Usually, this text is used to tell legends, folktales, myths. For example, this text can be used to tell the story of Lake Toba, Sigale-gale, Putri Hijau, etc.

Linguistic features such as material process can be examined through the transitivity patterns of the systemic functional grammar. Systemic Functional Linguistics (SFL) is a linguistic theory introduced by M.A.K. Halliday which stresses its study on the language as source of meaning that focuses the study on the discourse analysis. Moreover, SFL is a multi-perspective model, designed to prove analysts with complementary lenses for interpreting language in use [17]. So, SFL is viewed as the system of meaning and can be used to interpret language in multi-perspective area.

In narrative story such as Putri Hijau, Lake Toba, and Sigale-gale, there are local wisdom contents that can be found. Those stories originate from North Sumatera. One of cultural dimensions of local wisdom is cultural knowledge which is about cultural aspects such as values, traditions, languages, technologies, norms, etc. Legends, myths, and folklore are parts of cultural dimension of local wisdom and kinds of local wisdom can be obtained from the texts such as the legend of Lake Toba that contains politeness and commitment. Local wisdom content usually can be written in the coda of narrative text.

Based on the preliminary study conducted at English department, STKIP Tapanuli Selatan, it can be found that from narrative text produced by students, they still have difficulty in writing the text. They made some errors such as tenses, missing some lexicogrammatical features such as the absence of dialogue. The example of error in using tenses found in the data is presented as the following: "They already know that it is impossible that a tiger come to their village and gone without any trash in the morning".

So, the problem appears in the example above. The student has difficulty in distinguishing the use of tenses. The lecturer should know whether the text produced by student is suitable with the characteristics of the narrative itself or not. This kind of problem has to be solved in order to make them able to write this text properly.

Therefore, this study is aimed to investigate linguistic features and local wisdom content in EFL students' narrative texts and its pedagogical implementation. The findings of this research are expected to be useful as a reference for teacher and lecturers in teaching writing in Indonesia about the problem related to linguistic features so that they can give more attention in order to make better result of students' writing. 


\section{REVIEW OF RELATED LITERATURE}

\section{Systemic Functional Linguistics}

Systemic Functional Linguistics (SFL) is recognized as a very useful descriptive and interpretive framework for seeing language as a strategic, making-meaning resource [4]. Language has evolved (tens, hundreds, thousands and even millions of) years in response to the demand of the meta function. It is accordingly held that the structure of language or the text is determined by the function or purpose set by its speakers in using the language [14] Furthermore, Eggins [4] adds that systemic linguists make four main theoretical claims about language: (a) That language use is functional; (b) That its function is to make meaning; (c) That meaning is influenced by social and cultural contexts; and (d) That the process of using language is a semiotic process in which people make meanings by making linguistic choices. SFL also deals with the context.

Language has three main kinds of meanings simultaneously: ideational, interpersonal, and textual meanings [14]. These three kinds of meaning run throughout the whole of language, and in a fundamental respect they determine the way that language has evolved. They are referred to in systemic accounts of grammar as metafunctions [12]. Furthermore, Sinar [4] stating that metafunction of language are inherent in every language use in social contexts. In conclusion, there are three metafunctions of language i.e. ideational, interpersonal, and textual function which have the same status and function in social context.

Halliday and Matthiessen [12] argue that language provides a theory of human experience, and certain of the resources of the lexico-grammar of every language are dedicated to that function and it is called as ideational function. Ideational function is distinguished into two components namely experiential and logical function which is also called as clause as representation. A clause has meaning as an exchange, a transaction between speaker and listener; the Subject is the warranty of the exchange. It is the element the speaker makes responsible for the validity of what he is saying [12]. It is also known as interpersonal function. The last one is textual function which is also understood as clause as message which is realized by theme and rhyme. Halliday and Matthiessen [12] point out that a clause has meaning as a message, a quantum of information; the Theme is the point of departure for the message. It is the element the speaker selects for 'grounding' what he is going on to say. Those three metafunctions have equal status and utilized in social context.

\section{Writing}

Hoover [13] states that Writing is vital component of comprehensive synergy of literacy and being integrated by reading, listening, and speaking and a way to express the ideas in written form. Moreover, Graham and Perin [13], writing is formulating own thoughts which are drawn from the background of knowledge, organizing them, and creating a written record of them using the conventions of spelling and grammar. Writing orients to product but it does not ignore the process. Oshima and Hogue [19] strongly argue that writing specifically academic writing is not easy. The process of writing should be scrutinized by the writer. 


\section{Genre}

In the text, genre is realized by the structure of the text, which varies from one to another. However, there is an obligatory structure called as Genetic Structure Potential (GSP). It refers to a text structure that can be used to diagnose the social function of the genre. GSP itself includes the opening, the body, and the closure of the text. Each text has a different social function in which it needs the different genre and GSP (Martin, 1992). Additionally, Sarasagih (2012) explains that genre is defined as a staged, goaloriented social process. Genre also covers social process of how to behave in the society. In conclusion, genre is a frame of reference which covers a staged, and goaloriented in a particular society of culture.

Gerot and Wignell [8] assert that there are thirteen types of academic genre; spoof, recounts, reports, exposition, news item, anecdote, narrative, procedure, description, commentary, explanation, discussion, and reviews. Dirgeyasa (2014) gives a clear difference between each of academic genres in terms of social function and the generic structure.

\section{Narrative Text}

Gerot and Wignell (1994) assert that narrative text has communicative purpose namely in order to entertain the readers. Joyce \& Feez [15] also hold that narratives have some linguistic features as listed below: (1) Specific often individual participants with defined identities. Major participants are human, or sometimes animal with human characteristic; (2) Mainly use action verb (material processes), that describe what happens. This can be explored through transitivity analysis; (3) Normally use past tense; (4) Dialogue often includes and uses a number of saying verb (verbal process) such as said, asked, and replied. The tense may change to the present or future in the dialogue. Sometimes these saying verbs also indicate how something is said; (5) Descriptive language is use to enhance and develop the story by creating image in the reader's mind; (6) Can be written in the first person (I, we) or third person (he, she, they).

Anderson and Anderson [1] and Joyce and Feez [15] propose that the structures of narrative include orientation, complication, evaluation, resolution, and coda. Rustipa (2011) gives further explanation about schematic or generic structure of narrative text as the following:

Orientation. Orientation orients listener to what is to follow in terms of people, actions, time and place. The clauses are in simple past form. Temporal conjunctions, individualized participants, material processes are used in this stage.

Complication. Complication is the main section of a narrative. It presents sequenced events which culminate in a crisis or a problem. This Complication is realized in simple past mental, material processes, individualized participants.

Evaluation. Evaluation presents appraisal of crisis. Evaluation is mostly realized in attitudinal lexis.

Resolution. Resolution shows how crisis / complication is resolved. The mental, verbal, material, and simple past processes are used in this stage.

Coda. Coda is the concluding stage. The purpose is to make a point about the text as a whole. One of the functions of a Coda is to return the text to the present and by doing so to evaluate the whole event. Coda sometimes conveys comment of the narrator 
towards the significance of the narrative. Besides material, mental processes, appraisal lexis is also included in Coda.

\section{Local Wisdom}

Sibarani [22] states that the local wisdom is the community's wisdom or local genius deriving from the lofty value of cultural tradition in order to manage the community's social order or social life. He further adds that it can be observed scientifically from cultural product with in depth interpretation. There are 17 kinds of local wisdom i.e. welfare, hard-working, discipline, education, health, cooperation, gender-organization, cultural preservation and creativity, caring for the environment, peacefulness, social solidarity, politeness, honesty, harmony, commitment, positive thinking, thankfulness. Basically, there are 5 (five) cultural dimensions of local wisdom namely local knowledge, local culture, local skill, local human resources, and local social process (Ife, 2002).

\section{METHOD}

This study was conducted by using qualitative content analysis method. Cohen, Manion and Morrison [2] argue that qualitative content analysis is the process of summarizing and reporting written data - the main contents of data and their messages. Another expert, Singh [23] states that content analysis, sometimes known as document analysis deals with the systematic examination of current records or documents as sources of data. In documentary analysis, the following may be used as sources of data: official records and reports, printed forms, text-books, reference books, letters, autobiographies diaries, pictures, films and cartoons etc. So, content analysis is a method used to analyze the data in the written forms (documents) which is the focus of the analysis is the content of it.

The research was conducted at English Department of Sekolah Tinggi Keguruan dan Ilmu Pendidikan (STKIP) Tapanuli Selatan. The number of participants taken as sample was 25 students of fourth semester students. They are chosen because they have learned the materials about narrative text the method used in teaching writing is genrebased approach. The source of the data was collected from narrative text which the length of the text is $275-400$ words. The main instrument in this research was the researchers themselves and the secondary instrument was the writing sheets written by 25 students.

The data were analyzed by using some steps proposed by Ezzy [7] as the followings: (1 ) Recognizing the segments of the texts; (2) Identifying and analyzing the lexicogrammatical features of the text; (3) Analyzing local wisdom content in the text; (4) Inference making 


\section{RESULTS AND DISCUSSION}

\section{Results}

There are 12 titles of narrative text found in this study. They wrote types of narrative text such as legend, myth, and folklore a narrative text about legend, myth, and folklore which these common types found in North Sumatera. The titles found are "The Legend of the Snake Princess", "Putri Hijau", "The Origin of Pond Sampuraga", "Lake Toba", "Hanging Stone", "The Legend of Lake Marsabut", "The Legend of Kantan Island", "Beras Pulut", "The Legend of Losung Lake and Si Pinggan Lake", "Mata Diding", and "Sinakko".

In terms of lexico-grammatical features, it is illustrated that most of the students have difficulty in distinguishing the use of past tense or present tense including regular and irregular verbs, and the missing of dialogue existence. There are 21 students who have problem with tenses and grammar including the use of past tense, regular and irregular verb, and also preposition. There are only 4 texts which have no mistake in terms of grammar and the use of past tense namely text $21,18,17,12$. The problem in using past tense is presented in the following data: "Once, there was a kingdom in the area of Simalungun. The kingdom is led by a wise kin. Unfortunately, the princess had an ugly nature. She liked to say bad words. People call her a talkative princess". (Taken from text 1: The Legend of the Snake Princess)

From the data above, the student uses 'is' and 'call' in writing orientation of narrative text. The correct form that they should have written is 'was' and 'called'. It means that student has difficulty in distinguishing verb in simple present and simple past.

Joyce \& Feez [15] also specify that the existence of dialogue in narrative text is one of the lexicogrammatical features of the text. From the data, it is obviously seen that there are 13 texts do not contain dialogue in the text (text 2, 3, 5, 6, 7, 8, 10, 11, 13, 14, $15,16,23)$. It means that students still have problem in understanding and applying this lexicogrammatical features. The example of the existence of dialogue found in the text is illustrated as the following data: One day, he caught one fish, just one fish, a big beautiful fish. The fish could speak with him. The fish said "Don't kill me! I will be your wife".

And the fact, the fish was a beautiful one. The poor fisherman "Toba" was so happy. Before married, the girl said "Never tell my story with others". And he said, "Yes, I will do it". (Taken from text 2: The Legend of Lake Toba)

Dialogue is used to perform the interaction among characters, and sometimes to indicate the conflict among characters. In the data presented above, it also signals that there is an interaction between Toba and the fish.

The other linguistic features of narrative text such as individual participants with defined identities, mainly use action verb (material processes) which has been proved through transitivity analysis, normally use past tense, the use of dialogue, descriptive language, and written in the first person (I, we) or third person (he, she, they) are exist in the narrative text written by students.

In terms of local wisdom content, this part can be observed from the coda. The moral values are put forward in this part. From 25 texts, there are only 5 students who provided coda in their writing. It was found that the characteristics illustrated from the texts are keeping promise, obedience to parents, honesty, being not arrogant, and 
patience which are in line with Sibarani's concept about local wisdom characteristics. The other 20 students do not provide coda in their writing so that the local wisdom content cannot be identified.

\section{Discussion}

From the findings, it is obviously seen that most of the students have difficulty in distinguishing the use of past tense or present tense including regular and irregular verbs, and the missing of dialogue existence. The students also committed many mistakes in grammar such as the following data: "Once, there was a kingdom in the area of Simalungun. The kingdom is led by a wise king." (Text 1, paragraph 1)

The example illustrates that the student utilizes simple present tense (is) instead of using simple past (was). Since the story happened in the past time, the sentence should be written by using simple past tense. This problem occurs dominantly in the data.

Then, from the analysis of the local wisdom content, it is found that only 5 students from 25 students provide the coda. It is still not representative because the percentage of the students who know how to give moral values based on local wisdom characteristics is only $20 \%$ even though the moral values they wrote are appropriate with Sibarani's concept of local wisdom characteristics [22], it is also one of the points to be considered for lecturers in teaching this genre. Narrative text is unique because it has coda which contains the typical components, that is the moral value. One of the examples is from coda of the legend of Lake Toba. From the story, it can be obtained that the moral values found in coda of the legend is obeying parents, keeping promise (commitment), and patience. A child should obey his parents such as not to eat father's meal without permission, and parents should be patient in order not to lose his temper easily. The story also reveals that Toba did not keep his promise not to tell his son about the origin of his wife, as stated in the dialogue found in the narrative text entitled "The legend of Lake Toba" as the following;

Before married, the girl said "Never tell my story with others". And he said, "Yes, I will do it". (The legend of Lake Toba)

The implication of this research is the students' have not been able to write narrative texts properly due to some missing linguistic features. It is a serious problem that students need more practice in writing. A good writing should fulfill three characteristics, namely (1) social function, (2) linguistic/lexicogrammatical features, and (3) schematic structure of a certain text. The finding is also in line with Mulyaningsih's research (2013) which entitled "An Analysis of Students' Ability in Writing Narrative Text: A case Study at One Public Junior High Schools in Bandung. In this research, she found that the students from lower achiever level need more practice in writing a narrative text specifically in using lexicogrammatical features. She also suggested that students are given "direct telling" [1] of lexicogrammatical features of narrative text since many grammatical errors are still found. This "direct telling" technique can be used to strengthen students' understanding about lexicogrammatical features of narrative text. 


\section{CONCLUSION AND SUGGESTION}

It is generally discovered that most of the students have difficulties in distinguishing the use of past tense or present tense including regular and irregular verbs, and the missing of dialogue existence. From local wisdom content, the findings illustrate that coda is lack of moral values even though there are some characteristics of local wisdom content found from the data such as keeping promise, obedience to parents, honesty, being not arrogant, and patience. The implication is the students' narrative texts are not quite good in fulfilling linguistic features of the text.

Then, it is also suggested that students do more practices in writing this text and lecturers should take a deep attention in teaching this text in order to make students understand linguistic features and local wisdom content included in this text. The lecturer should implement a specific approach, strategy, or method in teaching narrative text in order to enhance students' ability and achievement in writing this text. The lecturer also can give extra practice in writing this text to students so that students can understand and use linguistic features, and insert local wisdom content in narrative text.

\section{REFERENCES}

[1] Anderson, K. \& Anderson, M. 2003. Text Types in English 2. Malaysia: The Modern Art Production Group.

[2] Cohen, L., Manion, L., and Morrison, K. 2007. Research Methods in Education (6 $6^{\text {th }}$ ed.). New York: Routledge.

[3] Dirgeyasa, I. W. 2014. College Academic Writing; a Genre Based Perspective. Medan:Unimed Press.

[4] Eggin, S. 1994. An lntroduction to Systemic Functional Linguistics. London: Printer.

[5] Eggins, S. 2004. An Introduction to Systemic Functional Linguistics. New York: Continuum.

[6] Emilia, E. 2010. Teaching Writing: Developing Critical Learners. Bandung: Rizky Press.

[7] Ezzy, D. 2012. Qualitative Analysis: Practice and Innovation. New South Wales: National Library of Australia.

[8] Gerot, L. and Wignel, P.1994. Making Sense of Functional Grammar. Cammeray, New South Wales: Antipodean Educational Enterprises.

[9] Graham, S. and Perin D. 2007. Effective Strategies to Improve Writing of Adolescents in Middle and High Schools. New York: Alliance for Excellent Education.

[10] Halliday, M.A.K. 1985. Spoken and Written Language.Geelong, Victoria:Deakin University Press.

[11] Halliday, M.A.K. 1994. An Introduction to Functional Grammar (2 ${ }^{\text {nd }}$ ed). London: Arnold.

[12] Halliday, M.A.K and Matthiessen C.M.I.M. 2014.An Introduction to Functional Grammar ( $4^{\text {rd }}$ ed.). London: Routledge.

[13] Hoover, K. 2008. Writing: An Essential Component of Literacy. Research Alignment for MM-H California Treasures, June: 1-2

[14] Ife, J. 2002. Community Development: Community-Based Alternatives in an Age of Globalisation. New South Wales: Longman Pearson Educations.

[15] Joyce, H., \& Feez,S. 2000. Writing Skills: Narrative and Non-fiction Text Types. Sydney: Phoenix Education Pty Ltd.

[16] Martin J.R 1992. English Text System and Structure.Amsterdam: Benjamins

[17] Martin, J.R. \& White, P.R.R. 2005.The language of Evaluation: Appraisal in English.London \& New York: Palgrave Macmillan.

[18] Nurlela. 2010. Representasi Leksikogramatika Teks Pidato Kenegaraan Presiden Soeharto dan Presiden Susilo Bambang Yudhoyono. [Dissertasi]. Medan: Universitas Sumatera Utara, Sekolah PascaSarjana.

[19] Oshima, et al. 1999.Writing Academic English. New York: Addison Wesley 
[20] Saragih, A. 2016.Empowering Students through Learning English in the Present Context of Indonesia.In Sinar (et.al).Proceedings: National Conference on Language and Culture; Medan: USU Press. Page 1-11.

[21] Saragih, A., Sumarsih.,\& Gurning, B. 2012. Bahasa dalam Budaya Pembelajaran. Medan: Bartong Jaya.

[22] Sibarani, R. 2012. Kearifan Lokal: Hakikat, Peran, dan Metode Tradisi Lisan. Jakarta. Asosiasi Tradisi Lisan.

[23] Singh, Y.K. 2006. Fundamental of Research Methodology and Statistics. New Delhi: New Age International (P) Limited.

[24] Sinar, T.S. 2007. Phasal and Experiential Realizations in Lecture Discourse: A SystemicFunctional Analysis. Medan: Koordinasi Perguruan Tinggi Swasta Wilayah- I NAD-Sumut. 